\title{
NURSING STUDENTS' VIEWS ON WORKING WITH CHILDREN WITH DISABILITIES
}

\author{
Monika Obreykova $^{1}$, Galina Terzieva $^{2}$
}

\begin{abstract}
:
Highly qualified nurses and regular training programs for innovative and efficient medical practices are very important for the provision of health care facilities for children with disabilities.

Purpose: To study the motives of nursing students for choosing to work with children with disabilities; to know about their opinion about the sufficiency of the duration of their internship and the undergraduate internship in centers for with children with disabilities; to understand the factors influencing the professional competencies of nursing students to work with children with disabilities.

Materials and methods: A survey was conducted among 219 students majoring in Nursing through a structured questionnaire.

Students expressed their opinion that the duration of the internship in institutions for children with disabilities should be increased $[\mathrm{t}(2017)=12.387$; p-level $<0.001]$. They indicated their willingness to work with children with disabilities [ $\mathrm{t}$ $(217)=15.432 ; \mathrm{p}$-level $<0.001]$. Students shared that they experience higher psycho-emotional stress while working with children with disabilities $[\mathrm{t}(217)=7.337$; $\mathrm{p}$-level $<0.001]$. They also believed that the introduction of an elective subject on children with certain types of disabilities would improve their preparedness [ $t(217)=8.562$; p-level $<0.001]$.

Conclusion: The study revealed that the nursing students believe that the present model of student training related to the care of children with disabilities require changes in the following ways: introduction of a separate module Nursing care for children with disabilities; introduction of an elective course on nursing care for children with disabilities; application of pedagogical and psychological approaches for developing the skills for coping with stress; increasing the duration of the internship in the fourth year of study for working with children with disabilities.
\end{abstract}

UDC Classification: 614.2, DOI: https://doi.org/10.12955/pmp.v2.183

Keywords: students, disabilities, children, motivation

\section{Introduction}

Problems in children with disabilities can be defined as psychological, pedagogical, medical, sociological, technical and informational difficulties. And it requires a high degree of responsibility and competence in the specialists in a multidisciplinary team to handle such children, and a nurse is at the core of such teams, as she will be there with the children 24 hours a day. Nurses, who are working with children with disabilities must not only be excellently trained but also have specialized social, pedagogical and psychological knowledge and competencies. The most important qualities of a nurse include mercy, compassion, cordiality, responsiveness, respect for the patient's autonomy, compassion, responsibility, justice, and humanity (Dragusheva and Petleshkova 2020). The specialized literature (Andonova, 2017; Draganova, 2017; Obreykova, 2019; Terzieva, 2009, Terzieva et al. 2011) in the field of health care reveals the potential of the educational processes in the development of competencies in nursing students. Some of the authors consider "the building of humane relations in the teacher-student system as a condition and factor for establishing the behavioral model of humane attitude of future specialists to the patient: in providing medical care; in the implementation of the preventive, promotional, pedagogical and social functions and activities of the medical specialist" (Taneva et al. 2017). The creation of conditions for "goal-setting by the trainee gives direction to the activity (s)he performs to realize the set goals, leads to the development of the trainee's personality, and helps him/her to master and validate his/her professional competencies" (Terzieva et al. 2014.). The main task of the teacher is to create such an evironement for the that helps students to gain theoretical knowledge and practical training about the subject. Other authors emphasized that developing effective communication between the patient and the medical team and define it as "a complex process". The main elements in it are verbal and non-verbal communication, personal qualities and professional competence of medical professionals based on mutual respect and respect for universal human values, as per the individual needs and characteristics of the patient (Andonova, 2017).

\footnotetext{
${ }^{1}$ University „Prof. Dr Asen Zlatarov“, Departament of Health care, Burgas, Bulgaria, monika_obrejkova@abv.bg

${ }^{2}$ University „Prof. Dr Asen Zlatarov“, Departament of Health care, Burgas, Bulgaria, galina.terzieva@abv.bg
} 
An important prerequisite for performing and improving the quality of health care for children with disabilities by nurses is their regular training to introduce innovative and good medical practices. (Terzieva et al. 2012).

The purpose of the research is to establish the motives for working with children with disabilities; the opinion about the duration of the internship and the undergraduate internship in institutions for work with children with disabilities; the factors influencing the professional competencies of students for work with children with disabilities.

\section{Data and methodology}

A survey among 219 nursing students from University "Prof. Dr. Asen Zlatarov"-Burgas and other medical universities was conducted through a structured questionnaire was conducted The questionnaire contained 29 questions. $22 \%$ of the students were in their second year, $43 \%$ in the third year and $35 \%$ were in their fourth year of university.

\section{Survey results}

The survey was conducted from 2017-20. Most of the respondents i.e. 74\% were aged between 18-25 years, $12 \%$ were in the group of 26-30 years, $6 \%$ in 31-35 years age group, and 7\% respondents were above 35 years of age (Figure 1):

\begin{tabular}{|r|c|}
\hline Figure 1: Age-wise Distribution of students \\
\hline & \\
over 35 & $7 \%$ \\
$31-35$ & $6 \%$ \\
$26-30$ & $12 \%$ \\
$18-25$ & \\
& \\
\hline Source: Authors & $74 \%$ \\
\hline
\end{tabular}

There is a compulsory course on "Nursing care for children and adults with disabilities" in the third year. To the question "Do you think that the studied discipline gives you the necessary theoretical knowledge and practical skills?" a high percentage of students answered affirmatively with "yes" $(52 \%), 36 \%$ responded with "rather yes", $10 \%$ responded with "Rather not", and only $2 \%$ with a clear "No" (Figure 2):

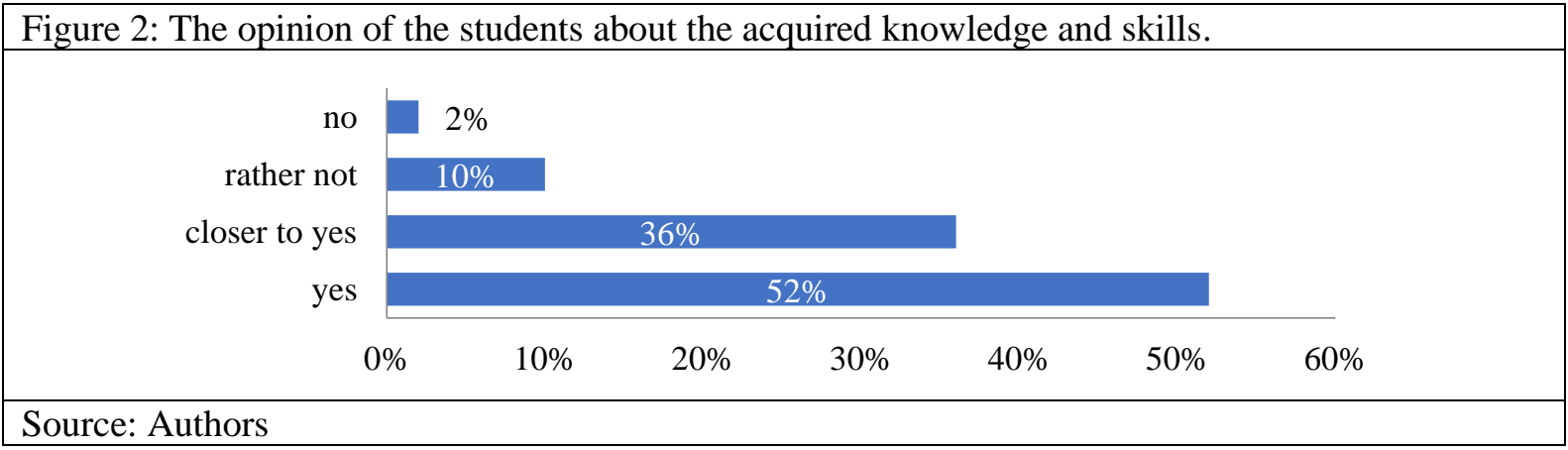

Table 1: Opportunity to validate different skills

\begin{tabular}{|c|l|r|r|}
\hline A & Manipulation skills & 72 & $33 \%$ \\
\hline B & Hygienic care skills & 136 & $62 \%$ \\
\hline C & Administrative skills & 13 & $6 \%$ \\
\hline D & Communication skills & 101 & $46 \%$ \\
\hline E & Ability to work in team & 84 & $38 \%$ \\
\hline F & $\begin{array}{l}\text { Skills for providing special nursing care for children accommodated in a home for } \\
\text { medical and social care for children }\end{array}$ & 108 & $49 \%$ \\
\hline G & Skills to assess the emotional state of the child & 50 & $23 \%$ \\
\hline H & Skills for preparing a care plan for a child with a disability & 105 & $48 \%$ \\
\hline
\end{tabular}

Source: Authors 
The opinion of the students on the possibility of developing skills to working with children with disabilities after studying the compulsory discipline has been studied. The results are shown in Table 1.

The results presented in the following figure outlined the students' assessment of the sufficiency of the number of hours assigned in the curriculum for clinical practice in centers where children with disabilities are taken care of. According to the students, there they received the necessary training, which is apparent from their responses. $40 \%$ of the students responded with "rather yes", "yes", $21 \%$ responded with "rather not" and 5\% responded with "no" (Figure 3):

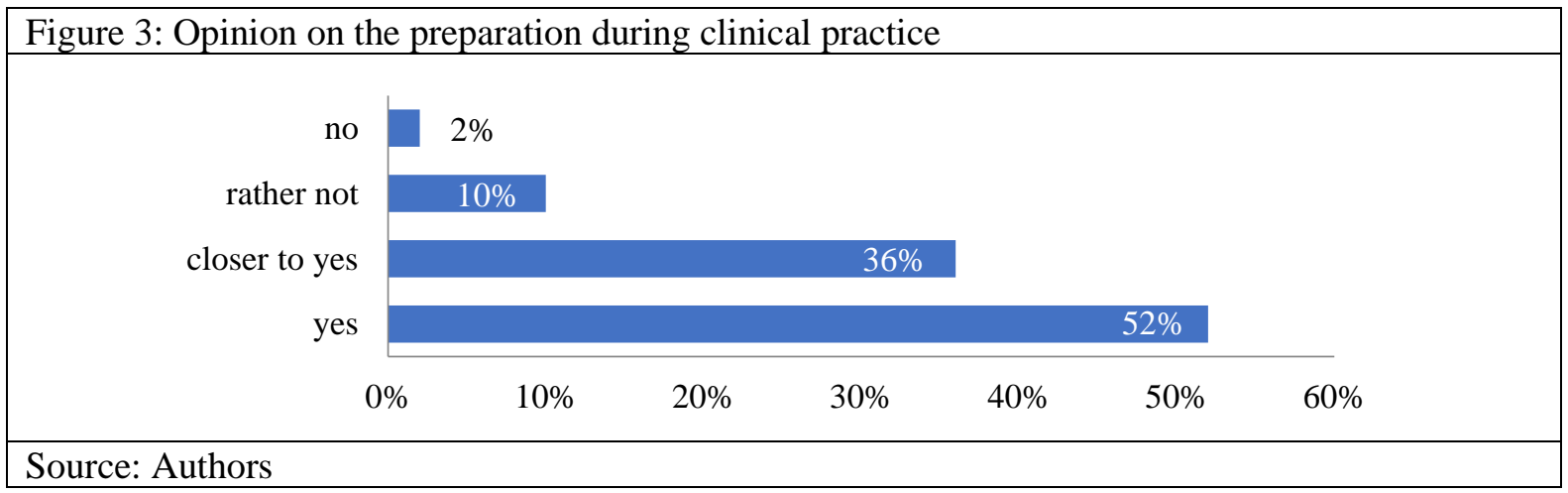

The data from the survey allowed us to identify the factors that positively affect the professional competencies of the students during the internship and before the diploma internship in centers for children with disabilities. The responses can be ranked as follows: practical skills and habits (69\%), theoretical knowledge (61\%), practical training in an institution conducted by a teacher (45\%), practical training in an institution conducted by a mentor (23\%), training course (35\%), personal qualities $(38 \%)$, the level of theoretical and practical training of students $(44 \%)$, the good material base in the institution $(21 \%)$.

$63 \%$ of students preferred to practice with a teacher, for the remaining $17 \%$ it does not matter with whom they practice: a teacher or mentor.

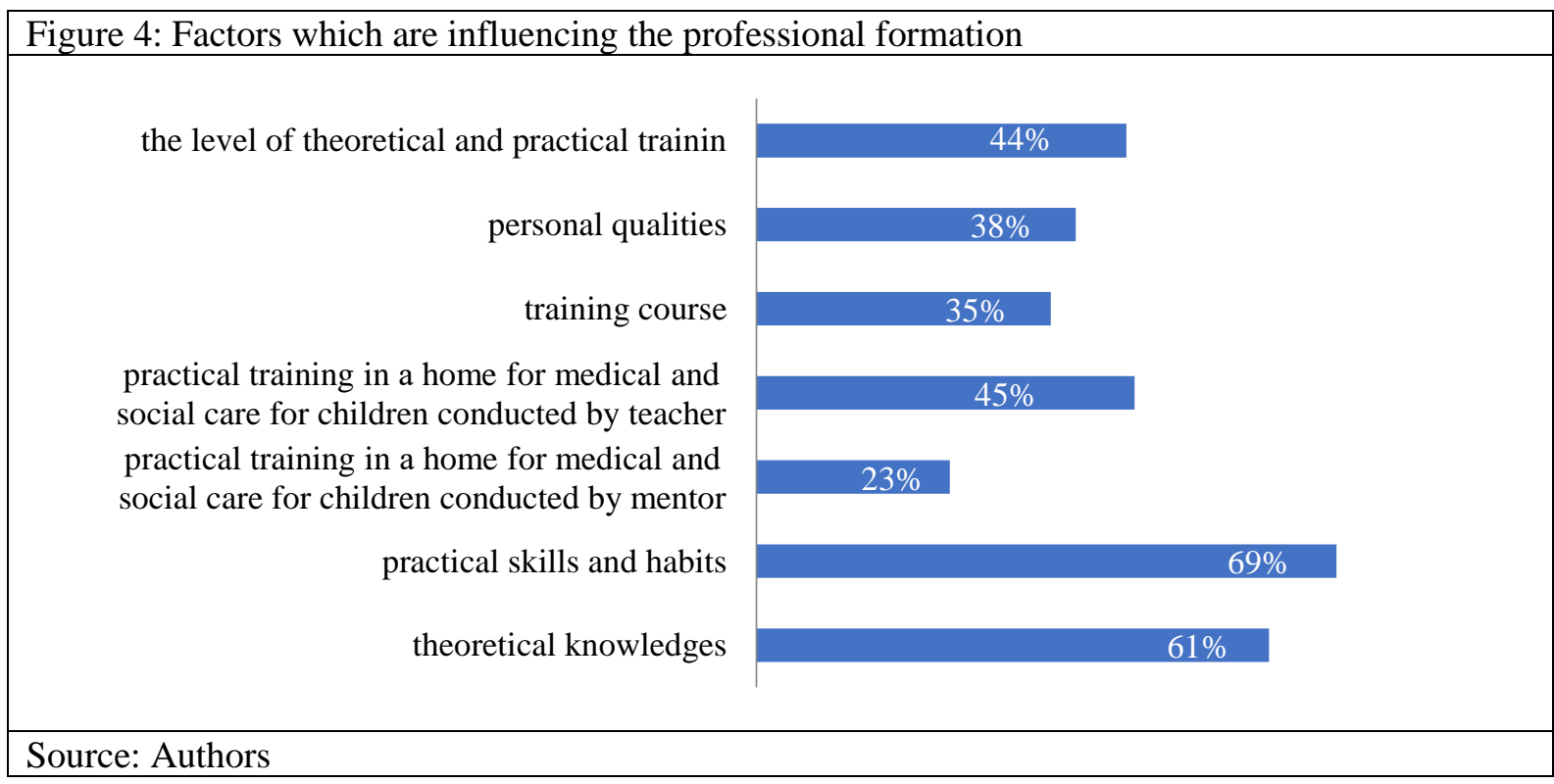

Figure 5 illustrates the students' opinion about the need for an elective course on the care of children with disabilities to increase their preparedness. To answer this, $44 \%$ of students responded with "yes", $35 \%$ with "rather yes", $14 \%$ with "rather no" and $7 \%$ with a clear "no".

Based on the obtained responses, it can be stated that an elective course on nursing care for children with disabilities can be developed. The purpose of the proposed curriculum should be to enhance the preparedness of students and to upgrade their already acquired knowledge and skills. Its inclusion in 
the curriculum of the course on nursing is possible. It is an administrative task and should be in accordance with the state requirements for specialisation training and the regulations of the University.

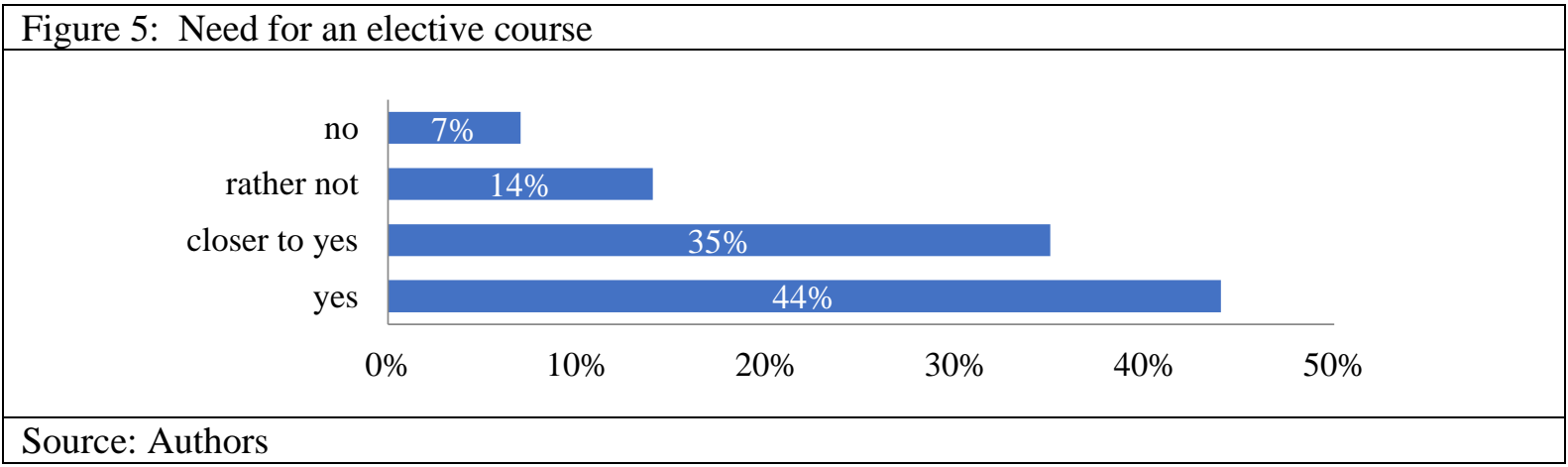

The students' opinion on dividing the compulsory course of "Nursing care for children and adults with disabilities" into two separate disciplines "Nursing care for children with disabilities" and "Nursing care for adults with disabilities" was obtained. According to $41 \%$ of the students, this division will optimize their preparedness, 33\% of students responded with "rather yes", while 17\% responded with "rather not" and only 9\% responded with a clear "no". (Figure 6).

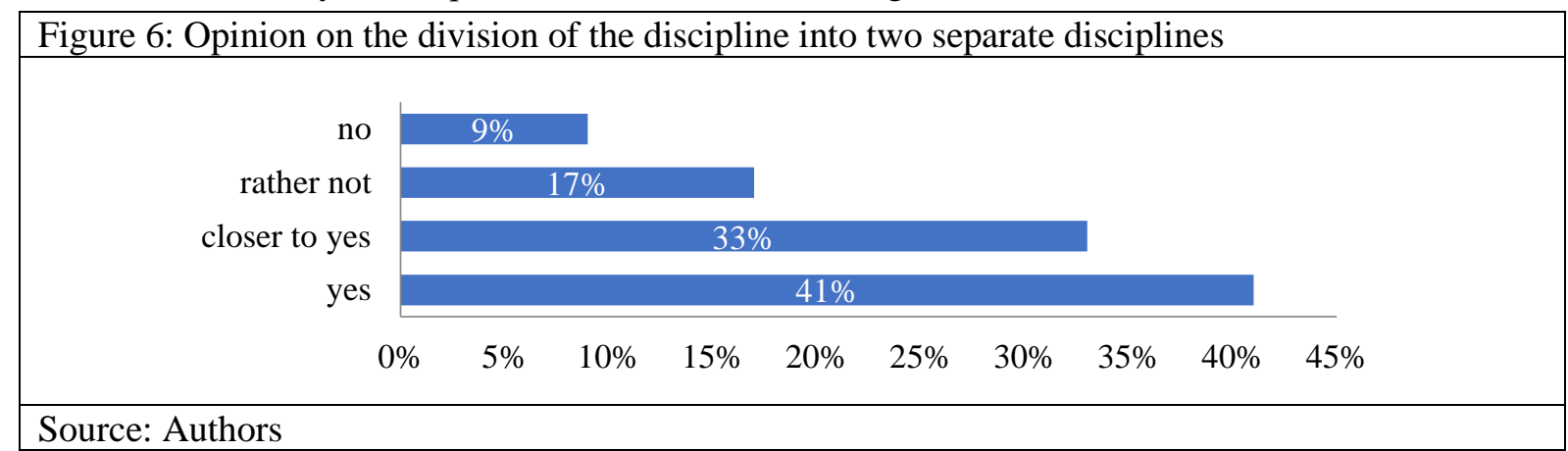

During the training period, 97\% of the students visited Day Care Centers for Children with Disabilities, as a part of their practical training, while the remaining 3\% of them had visited these centers on other occasions as well. From the observations during their visits, $27 \%$ of students rated the child care facilities as "sufficient", $28 \%$ rated the facilities as "rather sufficient", $32 \%$ of students said that it is "rather insufficient", while 13\% rated the facilities as insufficient. The last two observations emphasized the need to develop the competencies of health professionals to take care of children with disabilities. The postgraduate training courses should be conducted for working nurses to improve the quality of care for children with disabilities. As per the responses, multiple duties that nurses are required to perform on their job include medical services (79\%), social services (58\%), pedagogical (51\%), educative (27\%), communicative duties (44\%) and administrative duties (19\%). Prior knowledge about the multiple tasks that a nurse is required to perform while working with children with disabilities will influence the students to decide whether they would like to work with such institutions or not (Figure 7).

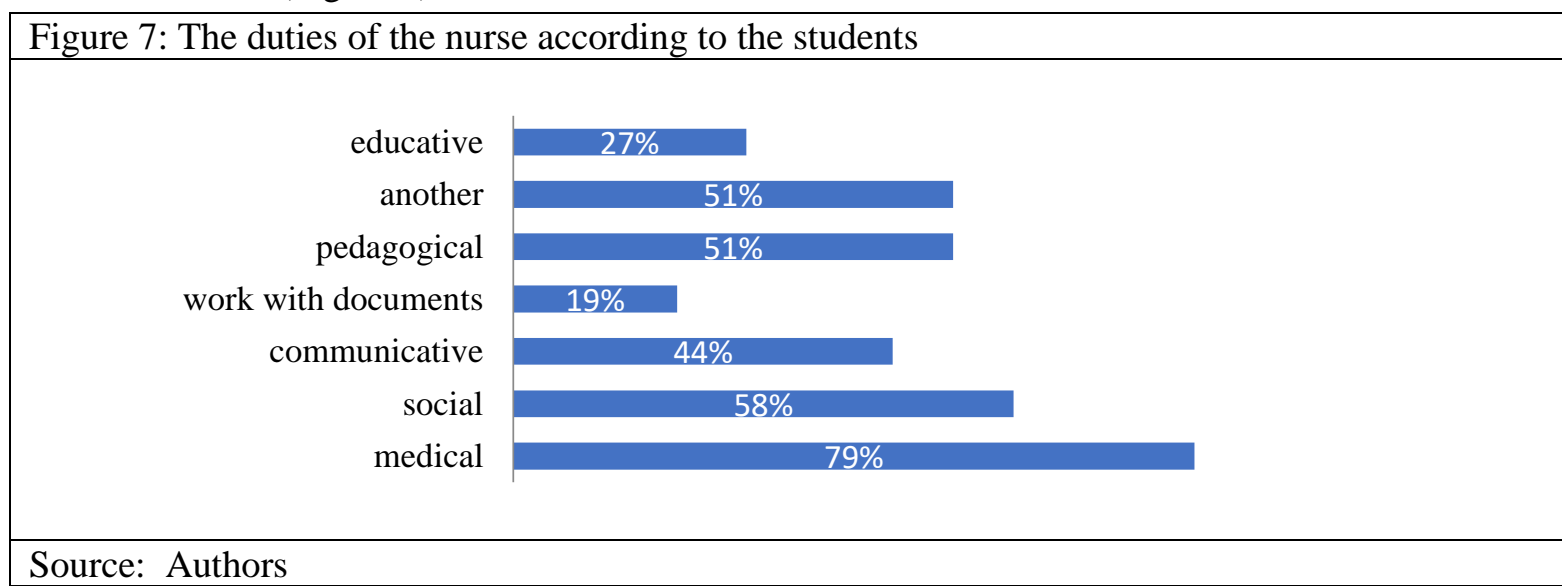


The findings regarding the factors influencing the choice of students to work in a center for the care of children with disabilities are presented in Table 2.

\begin{tabular}{|c|c|c|c|}
\hline & Factors & $\begin{array}{l}\text { Number of } \\
\text { students }\end{array}$ & $\%$ \\
\hline A & $\begin{array}{l}\text { Developing professional self-confidence by caring for children with } \\
\text { disabilities during the training period }\end{array}$ & 89 & $41 \%$ \\
\hline $\mathrm{B}$ & Exchange of experience in a European country during the training period & 63 & $29 \%$ \\
\hline $\mathrm{C}$ & Attractive reward & 135 & $62 \%$ \\
\hline $\mathrm{D}$ & Social privileges & 116 & $53 \%$ \\
\hline $\mathrm{E}$ & Good material base in the workplace & 114 & $52 \%$ \\
\hline $\mathrm{F}$ & Opportunity for postgraduate education for children with disabilities & 82 & $37 \%$ \\
\hline
\end{tabular}

Source: Authors

The main motive for choosing to work with children with disabilities as indicated by $69 \%$ of students is to improve the quality of life of such children, 54\% of the students wanted to enhance their practical skills, 53\% of the students wanted to gain theoretical knowledge on the problem, interaction with specialists in health care and work satisfaction are the motives reported by $43 \%$ respondents; developing communication skills is the motive for $21 \%$ of the students while $4 \%$ indicated other reasons.

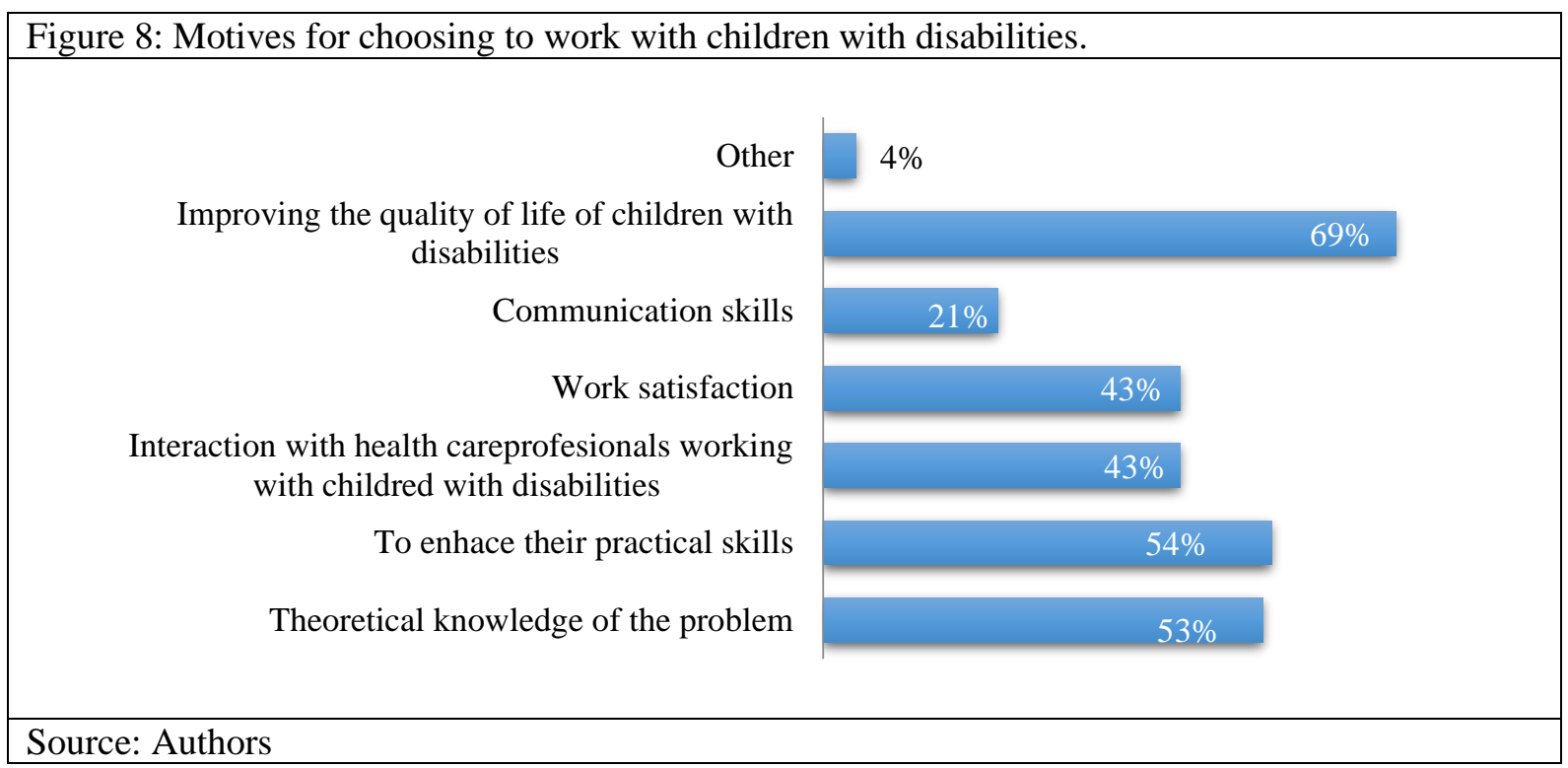

The motives for choosing not to work with children with disabilities as responded by the students are lack of professional experience (54\%), lack of sufficient practical skills (48\%), ignorance of health legislation $(5 \%)$, collision with negative emotions $(38 \%)$, workplace conditions - (35\%), and lack of motivation $(45 \%)$.

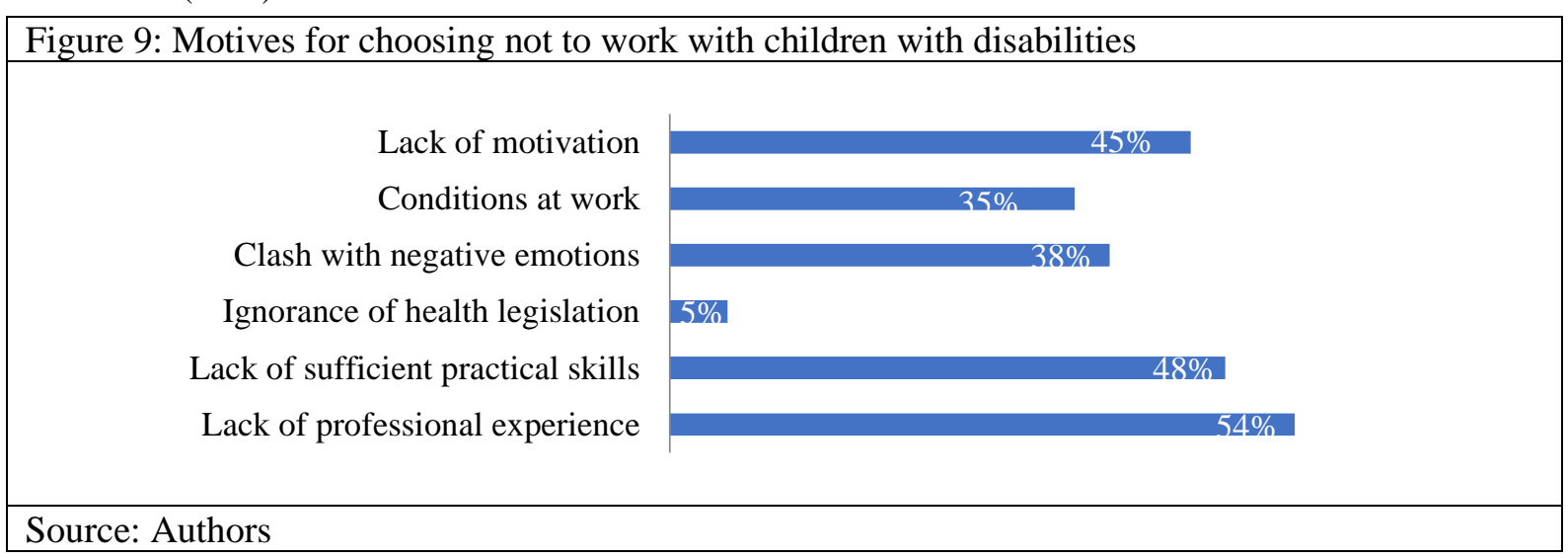


The results outlined that the majority of the student did not experience psycho-emotional stress while working with children with disabilities. While answering about experiencing psycho-emotional stress while working with children with disabilities, $40 \%$ of the students responded with "rather no", $20 \%$ a clear "no", $22 \%$ students experienced emotional stress, while 18\% responded with "closer to yes" (Figure 10). Still, students and trainees stated that they would choose to work with children with disabilities. The majority of the students (37\%) responded with "yes", 28\% with "rather yes", $25 \%$ with "rather no" and $10 \%$ with "no".

\begin{tabular}{|l} 
Figure 10: Results outlining psycho-emotional stress among students when working with children \\
disabilities \\
\hline $\begin{array}{r}\text { no } \\
\text { rather not } \\
\text { closer to yes } \\
\text { yes }\end{array}$
\end{tabular}

\section{Conclusion}

The study concludes that few changes are required in the course curriculum for nursing students related to the care of children with disabilities in the following areas: First, by dividing the compulsory course of "nursing care for children and adults with disabilities" into two specialized courses "nursing care for children with disabilities" (30 hours) and "nursing care for adults with disabilities". It will enhance the specific knowledge and skills required for working with these children; second by introducing an elective course "Nursing Care for Children with Disabilities" (15 hours) in the curriculum to upgrade and deepen the knowledge gained from the compulsory discipline. It will further improve the skills of the nursing students and will also improve their communication skills to connect with children and their families better. Third, we suggest that there should be a 3-week internship (120 hours) in the fourth year for the nursing students in the institutions for children with disabilities. This will increase the mandatory length of service for working with children with disabilities to a total of 240 hours. Fourth, we suggest that there should a focus on pedagogical and psychological approaches to develop the skills in the nursing students to deal with stress while working with students with disabilities.

\section{References}

Andonova, A. (2017). The Importance of Effective Communication in Medical Practice. In: Academic Journal Management and Education, Burgas, v. XIII (5), pp.9-12, http://www.conference-burgas.com/maevolumes/vol13/b5_v13.pdf

Draganova, D. (2017). Sestrinski grizhi pri detsa i vazrastni s uvrezhdaniya [Nursung care for children and adults with disabilities].. Izd. MEDIATEH- Pleven

Dragusheva S., Petleshkova P. Preddiplomnaya stazhirovka meditsinskih sestër-predposbllka postroeniya pravilynogo podhoda $k$ patsientu [Bachelor's degree in nursing is a prerequisite for bilding the right approach to the patient]. Monografia wieloautorska "Edukacja dorosłych w XXI wieku". Siedlce, Poland 2020; 55-65 ISBN 978-83-64884-15-3

Obreykova. M., (2019). Attitude to the Students of the Specialty Medical Nurses to Their Preparation for WorkWith Children With Disabilities. V. 15(5) In: Academic Journal Management and Education, Burgas, pp. 194-198, http://www.conferenceburgas.com/maevolumes/vol16/b5_v16.pdf

Taneva, D,Y. Cokova, R. Kacarska, A.. Kirkova. (2017). Sestrinski grizhi pri detsa i vazrastni s uvrezhdaniya [Nursing care for children and adults with disabilities,ed.] izd. VAP.

Terzieva, G. (2009). Klinichnata praktika, uslovie i faktor za utvarzhdavane na humannostta u studentite. [Clinical practice, condition and factor establishing humanity in students] In: Humanizatsiya i demokratizatsiya na universitetskoto obrazovanie, Sofia, pp. 313-319. Association of the Professors From Slavonic Countries /APSC/. ISBN 978-954-490-245-2.

Terzieva, G. (2012). Goal Setting and Goal Formation of a Probationer in Nursing Specialties - A Premise to a Formation of Professional Competencies. In: Academic Journal Management and Education, Burgas, v. 8, (3), pp. 136-141, ISSN 13126121.http://www.conference-burgas.com/journalen_mae.html

Terzieva, G., Z. Lecheva, K. Popova. (2011). Innovatory methodical aspects of quality improvement in the practical preparation of the students in nursing speciality (1 ${ }^{\text {st }}$ part). In: "Skripta Scientifica Medica, v. 43 (4), Varna, pp. 333.

Terzieva, A., N. Vasileva, G. Chaneva.(2014). "Problemi v obuchenieto po sestrinski grizhi za patsienti s uvrezhdaniya, [Problems in nursing education for patient with disabilities], In: Sestrinsko delo. 